\title{
Outbreak communication challenges when misinformation spreads on social media
}

\section{Desafios da comunicação de surtos epidêmicos quando a desinformação se espalha nas redes sociais \\ Desafíos en la comunicación de brotes epidémicos cuando se difunde información errónea en las redes sociales}

Santosh Vijaykumar ${ }^{1, a}$

santosh.vijaykumar@northumbria.ac.uk | https://orcid.org/0000-0003-1083-7966

Yan $\operatorname{Jin}^{2, b}$

yanjin@uga.edu | https://orcid.org/oooo-0003-4228-5529

Claudia Pagliari ${ }^{3, c}$

claudia.pagliari@ed.ac.uk | https://orcid.org/o0o0-0001-5791-7723

${ }^{1}$ Northumbria University, Department of Psychology. Newcastle upon Tyne, United Kingdom.

${ }^{2}$ University of Georgia, Grady School of Journalism and Mass Communication. Athens, GA, United States.

${ }^{3}$ University of Edinburgh, Usher Institute of Population Health Sciences and Informatics. Edinburgh, United Kingdom.

a Doutorado em Public Health Studies pela Saint Louis University.

${ }^{\mathrm{b}}$ Doutorado em Journalism pela University of Missouri.

c Doutorado em Psychology pela University of Edinburgh.

\begin{abstract}
This commentary analyses the implications of social media misinformation for global health risk communication. We define misinformation, describe the pathways through which it can adversely affect responses to risk communication efforts, highlight vulnerabilities in existing interventions and present an agenda for further research to understand and address this problem.
\end{abstract}

Keywords: Communication; Outbreak; Risk; Misinformation; Social media. 


\section{Resumo}

Este artigo analisa as implicações da desinformação nas mídias sociais para a comunicação global de riscos à saúde. Definimos desinformação, descrevemos os caminhos pelos quais ela pode afetar negativamente as respostas aos esforços de comunicação de risco, destacamos as vulnerabilidades nas intervenções existentes e apresentamos uma agenda para futuras pesquisas para entender e abordar esse problema.

Palavras-chave: Comunicação; Surto epidêmico; Risco; Desinformação; Mídias sociais.

\section{Resumen}

Este artículo analiza las implicaciones de la desinformación en las redes sociales para la comunicación de riesgos de salud global. Definimos información errónea, describimos los caminos por los cuales puede afectar de manera adversa las respuestas a los esfuerzos de comunicación de riesgos, resaltamos las vulnerabilidades en las intervenciones existentes y presentamos una agenda para futuras investigaciones para comprender y abordar este problema.

Palabras clave: Comunicación; Brote epidémico; Riesgo; Desinformación; Medios de comunicación social.

\section{Contribuição dos autores:}

Santosh Vijaykumar liderou a concepção e a escrita do trabalho.

Yan Jin e Claudia Pagliari colaboraram na concepção e na escrita.

Declaração de conflito de interesses: não há.

Fontes de financiamento: não houve.

Considerações éticas: não há.

Agradecimentos/Contribuições adicionais: não há.

Histórico do artigo: submetido: 28 fev. 2018 | aceito: 21 out. 2018 | publicado: 28 mar. 2019.

Apresentação anterior: não houve.

Licença CC BY-NC atribuição não comercial. Com essa licença é permitido acessar, baixar (download), copiar, imprimir, compartilhar, reutilizar e distribuir os artigos, desde que para uso não comercial e com a citação da fonte, conferindo os devidos créditos de autoria e menção à Reciis. Nesses casos, nenhuma permissão é necessária por parte dos autores ou dos editores. 


\section{The rise of digital misinformation during outbreaks}

As government officials in the southern Indian state of Kerala struggled to contain the 2018 outbreak of the bat-borne Nipah Virus (NiV), which eventually claimed 17 lives, a parallel outbreak of misinformation was spreading rapidly on social media, threatening to disrupt their efforts ${ }^{1}$. This included allegations that the outbreak was part of a corporate conspiracy to boost sales of mosquito repellent, specious claims that the virus is spread though eating chicken meat, and false reports of the virus having spread to unaffected areas. The government of Kerala released frequent press releases to counter the effects of this misinformation, which was causing confusion and alarm among an already panicked populace, and even arrested a group of young men behind one of these campaigns ${ }^{2}$. Beyond these corrective measures, however, public health agencies were unsure of how to stem the tide of misinformation campaigns, whose sources were often unclear and whose social vectors were beyond their control.

The NiV case is only the most recent example of this phenomenon, which has also been referred to as a form of 'digital pandemic' or 'misinfodemic', in which social media channels like WhatsApp, Twitter and Facebook have been playing a major role ${ }^{3,4}$. This has become a growing source of concern within the global health risk communication over the past five years, having featured in outbreaks across South America, Africa and South Asia ${ }^{5}$. Managing public responses to misinformation and developing interventions to limit its spread is thus a pressing global challenge, particularly given the growing penetration of social media low and middle income countries, where most outbreaks occur, coupled with the rising threat of infectious diseases in other parts of the world, where temperatures are rising due to global warming ${ }^{6}$.

\section{Misinformation, and how it spreads}

The term 'fake news' has been popularised by current US president Donald Trump, however this is an unhelpful construct with mixed connotations. Communication theorists often differentiate between "misinformation" - the presentation of information considered to be inaccurate by expert consensus", which may be unintentionally misleading, and "disinformation" which is spread with the deliberate intention to mislead. For the purpose of this commentary, however, we follow Southwell, Thorson, and Sheble's ${ }^{8}$ approach in seeing "disinformation as a special type of misinformation distinguished by the intent of the promoter". Misinformation can therefore be used as an over-arching term to encompass false information mistakenly shared, as well as rumours, conspiracy theories and lies deliberately shared in order to confuse, divert, frighten or manipulate the recipient. The sharing of misinformation comprises three key participants: 'Senders' who initiate the diffusion process, 'Spreaders' who forward such information and 'Receivers' who receive the information being diffused'

Infectious disease outbreaks provide an ideal context for the spread of misinformation. Often beginning as somewhat rare, mysterious, frightening or asymptomatic illnesses attributed to 'foreign' sources, news about infectious diseases is susceptible to rumour, embellishment and sensationalism. Just as these diseases themselves spread through social networks, so does the digital information that now accompanies them, whether for positive purposes such as official health messaging ${ }^{10}$ or the negative purposes already described ${ }^{11}$. Infectious disease misinformation affects a range of actors, such as policymakers, health agencies, the news media, faith-based organizations and the general public, who may communicate both within and across groups during an outbreak ${ }^{12}$. In such a charged environment, the cultural, religious and political agendas of each of these actors may intertwine with widespread panic, confusion, and the need to make sense of the situation, giving rise to speculative theories and explanations. Not surprisingly, misinformation campaigns are often characterized by low levels of knowledge. For instance, one message circulating on social media during the 2018 yellow fever outbreak in Brazil claimed that the vaccine for yellow fever could kill13, while another suggested that the outbreak was the result of a political conspiracy by the Brazilian government ${ }^{14}$. 
Having germinated, misinformation finds in social media an ideal vector that allows it to proliferate. Like infectious disease themselves, where a bacteria or virus spreads through physical networks, the structure of social media allows information to diffuse through online networks of individuals and groups connected on one or more platforms such as WhatsApp, Twitter or Facebook. Drawing on this analogy, scholars have analysed the spread of misinformation during Ebola using epidemiological modelling techniques and concluded that "the propagation of misinformation on Twitter can sometimes resemble that of genuine newsworthy events" 15 . This can prove particularly problematic as misinformation memes that circulate on social media often mask the identity of the original creator and could bear a striking resemblance to formal news stories. On encrypted platforms like WhatsApp, this means that users might often receive misinformation unsuspectingly shared by a family member or a friend, whom they are likely to trust. This relationship of trust can potentially lead message recipients to internalize the message, and even act upon it in a way that is health-harming. A case in point is two men in Nigeria who lost their lives after consuming copious amounts of salt water to protect themselves from Ebola, based on misinformation they received through social media ${ }^{16}$. In many ways these examples are not dissimilar to harmful folk myths, although with the internet and social media these may be spread rapidly and amplify at a global scale.

Social media platforms and smartphone capabilities can also empower users with tools to modify the original text, image, sound and video, to suit their preferences. These can exacerbate the problem by creating further opportunities for misinformation to be modified and spread virally in a way that can be hard to monitor or verify. Examples include taking and editing an image found in one source and recirculating it via social media, using algorithmic social bots to rapidly spread messages, and hiding the true source of the message via "astroturfing" ${ }^{\prime \prime}$. These computer programs may exploit the "echo chamber 'effect by distributing content that is tailored to users' cognitive biases and information preferences, so that they are more likely to believe $i^{18}$.

Considered at a population level, it is easy to see why social media misinformation could worsen prevailing levels of public anxiety and harbour false beliefs. Nearly half of the world's population is now connected through social media platforms and use of these platforms is widespread in the global regions most susceptible to IDOs ${ }^{19}$. These regions combine unprecedented levels of smartphone penetration with low levels of health literacy and political tensions, making populations ever more susceptible to the influence of pseudo-normative beliefs. New evidence shows how fake news travels faster than the truth and reaches more people while so doing ${ }^{20}$. In such an environment, misinformation can seriously disrupt formal risk communication efforts that seek to allay public concern through disseminating scientifically valid and preventive information.

\section{How misinformation affects outbreak communication efforts}

During public health crises such as IDOs, an immense and immediate need for crisis information and effective risk communication is created ${ }^{21}$. Consistent with the World Health Organization's (WHO) recommendations ${ }^{22}$, public health agencies are expected to respond to this need by managing the communication environment during three stages: preparedness, response, and recovery. The 'preparedness phase' involves assessing the information needs of the public and cultivating relationships of trust with stakeholders who can be effective allies in the dissemination process, such as the news media, community and religious groups, and social influencers. The 'response phase', which is arguably the most challenging, arrives after an outbreak has been announced. Here, the focus is on leveraging the relationships built through preparedness activities to implement a communication strategy that involves reliable spokespersons, transparent updates of the situation, clear communication of uncertainty, and intelligible presentation of information. Effective communication strategies are those that are successfully able to contain public concern while sufficiently informing citizens about the threat, as well as influencing them to undertake preventive actions. Most public health agencies now employ social media tools with varying levels of reach and impact for public outreach and communication during IDOs. While the aim is to instil confidence through clear communications based on scientific evidence, 
evolving levels of fear, anxiety, and panic will mean that the risk communication community must be equipped with tools and strategies that are sufficiently dynamic to respond to situations as they evolve. Efforts during the 'recovery phase' are focused on reiterating messages to encourage personal protective behaviour and chronicle the lessons learned to inform the next round of the risk communication cycle.

Misinformation specific to IDOs usually disrupts risk communication activities in the response phase, causing a cascade of casualties. The first of these is the intentional or unintentional challenge to scientific information being disseminated by public health authorities. Infused with doubt and confronted by even more uncertainty, individuals or communities exposed could react in a number of ways to the new burst of information that challenges their existing knowledge and understanding of the problem. Being exposed to misinformation early on in an outbreak may cause people to form and thereafter persist with opinions that differ substantially from those they would have had if they had been correctly informed ${ }^{23}$. The spread of (mis)information can thus shape perceptions of reality, with important consequences for choices about prevention or treatment ${ }^{24}$. These psychological effects can vary between demographic or psychological groups. In one study, for example, older adults with more education, liberal political views, and good analytical skills were better at discerning real news from "fake news" ${ }^{25}$. Personality may also play a role; for example, studies have observed that extraverted individuals are more likely to share misinformation whereas those with high conscientiousness were less likely to do so $^{26}$.

In a public health emergency misinformation may complicate situational awareness of an incident, defined as the "ability to identify, process and comprehend critical elements of an incident or situation" ${ }^{27}$. Doubting the credibility of the information being disseminated by health agencies can also undermine their authority of public health officials, putting them at risk, thus making it more difficult for effective interventions to reach their intended recipients. A recent analysis of Youtube videos revealed how online misinformation has contributed to public hesitancy to be vaccinated in Italy ${ }^{27}$. In these ways, misinformation can disrupt a carefully choreographed health communication strategy on the part of official agencies tasked with managing the situation. Most critically, misinformation can create fissures in trust between communities and health agencies, widely acknowledged as the cornerstone of any risk communication programme.

\section{The dichotomy of corrective information}

Public health agencies faced with the twin spread of infectious disease and social media misinformation face an uphill struggle. The novelty of this phenomenon means that few successful precedents, impact case studies, or guidelines are available to inform these strategies. Secondly, countering misinformation by disseminating corrective information is a double-edged sword. To investigate how misinformation can be refuted during a public health crisis, de Meer and $\mathrm{Jin}^{28}$ conducted an online experiment in the U.S. where they exposed participants to misinformation, followed by different types of corrective information (simple rebuttal vs. factual elaboration) supposedly from different sources (government health agency vs. news media vs. social peer). The corrective information helped to change participants' beliefs based on previous misinformation, whilst exposure to factual elaboration ${ }^{\mathrm{i}}$ made them more likely to take protective actions. Messages sent from government agencies and news media sources were found to be successful in improving belief accuracy. However, other research has demonstrated that corrective messaging strategies can paradoxically reduce intention to undertake scientifically recommended behaviours like vaccine uptake and may even exacerbate beliefs in misinformation ${ }^{29,30}$. Biases involved in interpreting evidence and resistance to scientific information weaken the impact of corrective information on ameliorating misinformation beliefs ${ }^{29,31,32}$. Members of the Ebola Response Anthropology Platform critiqued the use of

i Factual elaboration refers to elaborated factual detail of the corrective information that aims to refute factual error contained in the misinformation. 
corrective information during the 2014 Ebola outbreak explaining that messages driven purely by a clinical or epidemiological framing of the problem are unlikely to work unless they are sensitive to "the historical, political, economic and social contexts in which they are delivered”33.

\section{Gaps in health system responses to misinformation and opportunities for improvement}

While better uses of information from web searches, social media and participatory surveillance systems are helping global and local health agencies to better track and manage emerging outbreaks, handling the spread of misinformation represents an increasing and unwelcome burden, which risks lives, as the resurgence of measles in response to alarmist anti-vaccine campaigns is now demonstrating in parts of Europe $^{34}$. In response, online volunteer groups and health agencies are using Facebook groups, Twitter and Instagram to counter misinformation and respond to public queries triggered by misinformation ${ }^{35}$. The US Centres for Disease Control offers guidelines to encounter misinformation and rumours on its website and provides specific strategies that health agencies can use while dealing with misinformation in the news media $^{36,37}$. In addition to technological solutions, health authorities in countries like India are beginning to treat misinformation as a form of cybercrime and taking punitive action against offenders. During the NiV outbreak, the state government tracked and arrested 12 individuals on charges of forgery. These individuals had used their Facebook accounts to spread a warning masquerading as a state health department directive cautioning people against buying poultry products ${ }^{2}$. Other countries have introduced or considering new laws which specifically target the spreading of false information online; for example Malaysia has recently introduced a penalty of up to six years for doing $\mathrm{so}^{38}$.

The abovementioned responses to tackling misinformation offer encouraging signs that responsible public health agencies are actively seeking to address this problem. However, in order to combat misinformation and lessen its impacts, health systems must develop mechanisms to keep pace with the rate of misinformation and the emergent technologies that are fuelling its rapid spread. The first step in that process is to acknowledge the limitations of traditional corrective messaging strategies and develop novel approaches to improving public understanding in the face of misinformation.

A review commissioned by WHO found that tracking misinformation memes on social media platforms, and superseding them with accurate information bearing similar hashtags might be one useful approach ${ }^{39,40}$. Bode and Vraga ${ }^{23}$ recommend that health agencies disseminate corrective information through individual users as opposed to through algorithms, based on an experiment comparing the two approaches. These low hanging solutions need to be bolstered by a fundamental understanding of the structure of misinformation contagion in online spaces and the most effective mechanisms by which to impede its spread ${ }^{3}$. Evidence is not yet available to document public health agencies' use of tools like Hoaxy and Botometer ${ }^{18}$ or commercial social listening platforms. Further work is required to articulate the institutional arrangements needed to facilitate such collaborations. A critical consideration is how to leverage new streams of expertise and resources in a manner that avoids placing even greater economic pressure on the public health establishment. In this respect, organised, crowd-sourcing approaches hold promise, much as these are helping to suppress other types of 'fake news' and toxic online practices. The scale of the problem demands global networks of appropriately trained misinformation 'sentinels', just as these are required for spotting and tracking outbreak indicators in context ${ }^{10}$. In addition to harnessing the 'social machine' for good, developing global agreements to classify and manage deliberately misleading and potentially harmful information under the framework of cybersecurity warrants further attention.

While punitive measures, such as those seen in India, might help to curtail future behaviour, these approaches also provoke ethical dilemmas, such as how to balance the right to freedom of expression 
and public safety; or 'social listening' to identify health misinformation versus protecting citizens' privacy. The stakes are raised where such behaviour is criminalised, as can be seen in the debate over freedom of speech prompted by Facebook's recent banning of Alex Jones, whose social media channel 'Infowars' has been used to divide and confuse the public about issues such as gun control and vaccination ${ }^{41}$.Getting the balance right is challenging in a global context, since governments' can differ widely in their attitudes towards human rights raising the potential for social media monitoring 'in the public interest' to be misused for political gain or control.

Given the twin threats of IDO and misinformation contagion, alongside the dilemmas described, it is incumbent upon the global public health community to come together to develop agreements, guidelines and strategies for tackling misinformation, appropriate and sophisticated methodologies for doing so, and ethicolegal frameworks for using these approaches in the public interest. This will require high-level buy in, multistakeholder involvement and interdisciplinary thinking. Innovations such as machine learning for recognising misinformation patterns) ${ }^{42}$, blockchain for verifying trustworthy sources ${ }^{43}$ and crowdsourced fact-checking ${ }^{44}$ also offer promising opportunities for further development.

\section{Conclusions and recommendations}

As the risk of infectious disease pandemics rises worldwide, the problem of social media misinformation is becoming ever more of a threat to global health and security. Recent outbreaks, where this obstructed public health communication efforts, offer the chance to study the dynamics and effects of digital contagion retrospectively, while the data sciences present opportunities for innovation in the real-time surveillance and control of outbreak misinformation. Without human collaboration and intervention at the national and global levels, however, such methods will only achieve so much. We urge public health agencies, health communication experts and governments to come together in an effort to develop agreements and guidelines to advance the scientific, practical and policy innovation necessary to tackle this problem. We also urge new efforts to better understand how citizens perceive and balance the need for public health protection and their rights to information access, free speech and privacy, to ensure that these innovations are both responsible and ethical.

\section{References}

1. Jacob J. Kerala fighting Nipah and misinformation simultaneously. India Today [Internet]. 2018 May 23 [cited 2018 Oct 4]. Available from: https://www.indiatoday.in/india/story/kerala-fighting-nipah-andmisinformation-simultaneously-1239440-2018-05-23

2. A vector of misinformation. The Hindu. [Internet]. 2018 Jun 06 [cited 2018 Oct 4]. Available from: https://www.thehindu.com/news/national/kerala/a-vector-of-misinformation/article24091183.ece

3. Seymour B, Getman R, Saraf A, Zhang LH, Kalenderian E. When advocacy obscures accuracy online: digital pandemics of public health misinformation through an antifluoride case study. Am J Public Health. 2015;105(3):517-23. doi: https://doi.org/10.2105/AJPH.2014.302437

4. Gyenes N, Mina X. How misinfodemics spread disease. The Atlantic [Internet]. 2018 Aug 30 [cited 2018 Oct 4]. Available from: https://www.theatlantic.com/technology/archive/2018/08/how-misinfodemicsspread-disease/568921/

5. Larson H, Piot P. Fake news and distrust of science could lead to global epidemics. Wired [Internet]. 2018 Jan 9 [cited 2018 Oct 4]. Available from: https://www.wired.co.uk/article/how-fake-news-couldlead-to-epidemics

6. McVeigh K. Tropical disease outbreaks are growing threat in Europe as temperatures rise. The Guardian [Internet]. 2018 Aug 23 [cited 2018 Oct 4]. Available from: https://www.theguardian.com/globaldevelopment/2018/aug/23/tropical-disease-outbreaks-are-growing-threat-in-europe-as-temperatures-rise 
7. Tan AS, Lee C, Chae J. Exposure to health (mis) information: Lagged effects on young adults' health behaviors and potential pathways. J Com. 2015;65(4):674-98. doi: https://doi.org/10.1111/jcom.12163

8. Southwell BG, Thorson EA, Sheble L. Misinformation among mass audiences as a focus for inquiry. In: Southwell BG, Thorson EA, Sheble L, editors. Misinformation and mass audiences. Austin (TX): University of Texas Press; 2018. p. 1-11.

9. Wu L, Morstatter F, Hu X, Liu H. Mining misinformation in social media. In: Thai MT, Wu, Xiong H. Big Data in Complex and Social Networks. Boca Raton (FL): CRC Press; 2016. p. 123-52.

10. Pagliari C, Vijaykumar S. Digital Participatory Surveillance and the zika crisis: opportunities and caveats. PLoS Negl Trop Dis. 2016;10(6):e0004795. doi: https://doi.org/10.1371/journal.pntd.0004795

11. Goel S, Anderson A, Hofman J, Watts DJ. The structural virality of online diffusion. Manage Sci. 2015;62(1):180-96. doi: https://doi.org/10.1287/mnsc.2015.2158

12. Vijaykumar S, Jin Y, Nowak G. Social media and the virality of risk: the risk amplification through media spread (RAMS) model. J Homel Secur Emerg. 2015;12(3):653-77. doi: https://doi.org/10.1515/jhsem-2014-0072

13. DiLorenzo S. Rumors, mistrust hinder Brazil yellow fever vaccine campaign. Associated Press [Internet]. 2018 Mar 12 [cited 2018 Oct 4]. Available from: https://www.apnews.com/ea2f76fcd9594280a2287b9382d61e43

14. Molteni M. When WhatsApp's fake news problem threatens public health. Wired [Internet]. 2018 Sept 3 [cited 2018 Oct 4]. Available from: https://www.wired.com/story/when-whatsapps-fake-newsproblem-threatens-public-health/.

15. Jin F, Wang W, Zhao L, Dougherty E, Cao Y, Lu C-T, et al. Misinformation propagation in the age of Twitter. IEEE Computer. 2014;47(12):90-4. doi: https://doi.org/10.1109/MC.2014.361

16. Oyeyemi SO, Gabarron E, Wynn R. Ebola, Twitter, and misinformation: a dangerous combination? BMJ. 2014;349:g6178. doi: https://doi.org/10.1136/bmj.g6178

17. Menczer F. The spread of misinformation in social media. In: Proceedings of the 25th International Conference Companion on World Wide Web. Montréal: International World Wide Web Conferences Steering Committee; 2016. p. 717. doi: https://doi.org/10.1145/2872518.2890092

18. Ciampaglia GL, Menczer F. Biases make people vulnerable to misinformation spread by social media. Scientific American [Internet]. 2018 Jun 21 [cited 2018 Oct 4]. Available from: https://www. scientificamerican.com/article/biases-make-people-vulnerable-to-misinformation-spread-by-social-media/

19. Statista. Global social network penetration rate as of January 2019, by region 2019 [Internet]. 2018 [cited 2018 Oct 4]. Available from: https://www.statista.com/statistics/269615/social-network-penetration-by-region/

20. Vosoughi S, Roy D, Aral S. The spread of true and false news online. Science. 2018;359(6380):1146-51. doi: https://doi.org./10.1126/science.aap9559

21. Thelwall M, Stuart D. RUOK? Blogging communication technologies during crises. J Comput-Mediat Comm. 2007;12(2):523-48. doi: https://doi.org/10.1111/j.1083-6101.2007.00336.x

22. World Health Organization. World Health Organization Outbreak Communication Planning Guide. Geneva, Switzerland: World Health Organization; 2008.

23. Bode L, Vraga EK. See something, say something: correction of global health misinformation on social media. Health Commun. 2018;33(9):1131-40. doi: https://doi.org/10.1080/10410236.2017.1331312

24. Tafuri S, Gallone MS, Cappelli MG, Martinelli D, Prato R, Germinario C. Addressing the anti-vaccination movement and the role of HCWs. Vaccine. 2014;32(38):4860-5. doi: https://doi.org/10.1016/j. vaccine.2013.11.006

25. Pennycook G, Rand DG. Who falls for fake news? The roles of bullshit receptivity, overclaiming, familiarity, and analytic thinking. 2018 [citaed. https://dx.doi.org/10.2139/ssrn.3023545

26. Chen X, Sin SCJ. 'Misinformation? What of it?' Motivations and individual differences in misinformation sharing on social media. P Am Soc Info Sci Tech. 2013;50(1):1-4. doi: https://doi.org/10.1002/meet.14505001102

27. Lindsay BR. Social media and disasters: Current uses, future options, and policy considerations. Congressional Research Service Washington, DC; 2011

28. Donzelli G, Palomba G, Federigi I, Aquino F, Cioni L, Verani M et al. Misinformation on vaccination: a quantitative analysis of YouTube videos. Hum Vaccin Immunother. 2018;14(7):1654-59. doi: https://doi. org/10.1080/21645515.2018.1454572 
29. Van der Meer TGLA, Jin Y. Seeking formula for misinformation treatment in public health crises: the effects of corrective information type and source. Health Commun. 2019. doi: https://doi.org/10.1080/1 0410236.2019 .1573295

30. Nyhan B, Reifler J. When corrections fail: The persistence of political misperceptions. Polit Behav. 2010;32(2):303-30. doi: https://doi.org/10.1007/s11109-010-9112-2

31. Nyhan B, Reifler J. Does correcting myths about the flu vaccine work? An experimental evaluation of the effects of corrective information. Vaccine. 2015;33(3):459-64. doi: https://doi.org/10.1016/j. vaccine.2014.11.017

32. Kuklinski JH, Quirk PJ, Jerit J, Schwieder D, Rich RF. Misinformation and the currency of democratic citizenship. J Polit. 2000;62(3):790-816.

33. Nyhan B, Reifler J, Richey S, Freed GL. Effective messages in vaccine promotion: a randomized trial. Pediatrics. 2014;133(4):2013-365. doi: http://doi.org/10.1542/peds.2013-2365

34. Chandler C, Fairhead J, Kelly A, Leach M, Martineau F, Mokuwa E, et al. Ebola: limitations of correcting misinformation. The Lancet. 2015;385(9975):1275-7. doi: https://doi.org/10.1016/S0140-6736(14)62382-5

35. Larson $\mathrm{H}$. To wipe out measles, governments must regain social trust. Financial Times [Internet]. 201821 [cited 2018 Oct 4]. Available from: https://www.ft.com/content/ba579972-1baa-11e8-956a-43db76e69936

36. Sarmah S. Fighting the endless spread of Ebola misinformation on social media. Fast Company [Internet]. 2014 Aug. 19 [cited 2018 Oct 4]. Available from: https://www.fastcompany.com/3034380/ fighting-the-endless-spread-of-ebola-misinformation-on-social-media

37. Centers for Disease Control and Prevention. Responding to rumors and misinformation [Internet]. 2017 [cited 2018 Oct 4]. Available from: https://emergency.cdc.gov/cerc/cerccorner/article 072216.asp

38. Centers for Disease Control and Prevention. Managing misinformation in the media [Internet]. 2017 [cited 2018 Oct 4]. Available from: https://emergency.cdc.gov/cerc/cerccorner/article 121616.asp

39. Priday R. Fake news laws are threatening free speech on a global scale. Wired [Internet]. 2018 Apr. 5 [cited 2018 Oct 4]. Available from: https://www.wired.co.uk/article/malaysia-fake-news-law-uk-india-free-speech

40. Toppenberg-Pejcic D, Noyes J, Allen T, Alexander N, Vanderford M, Gamhewage G. Emergency risk communication: lessons learned from a rapid review of recent gray literature on Ebola, Zika, and yellow fever. Health Commun. 2018:1-19. doi: https://doi.org/10.1080/10410236.2017.1405488

41. Sopory P, Wilkins L. Evidence synthesis to support the guideline on emergency risk communication [Internet]. World Health Organization; 2016 [cited 2018 Oct 4]. Available from: http://www.who.int/riskcommunication/guidance/process/Q10-Final-Report.pdf?ua=1.

42. Twitter bans Alex Jones and Infowars for abusive behaviour. BBC News [Internet]. 2018 Sept. 6 [cited 2018 Oct 4]. Available from: https://www.bbc.co.uk/news/world-us-canada-45442417

43. Conroy NJ, Rubin VL, Chen Y. Automatic deception detection: methods for finding fake news. Proceedings of the Association for Information Science and Technology. 2015. doi: https://doi. org/10.1002/pra2.2015.145052010082

44. Partz H. European Commission to fight fake news with power of blockchain. Cointelegraph [Internet] 2018 [cited 2018 Oct 4]. Available from: https://cointelegraph.com/news/european-commission-to-fightfake-news-with-power-of-blockchain

45. Starbird K. Slowing the spread of viral misinformation: can crowdsourcing help? Huffington Post [Internet]. 2016 Dec. 21 [cited 2018 Oct 4]. Available from: https://www.huffingtonpost.com/entry/slowing-thespread-of-viral-misinformation-can-crowdsourcing us 58594084e4b0630a254235a7? guccounter $=1$ 